\title{
ДОСЛІДЖЕННЯ АНТИЕКСУДАТИВНОЇ АКТИВНОСТІ ЕКСТРАКТІВ 3 ЛИСТЯ SALVIA OFFICINALIS
}

Вступ. Удосконалення фрармакотерапії запалення є актуальним завданням сучасної фрармацевтичної та медичної науки.

Мета дослідження - вивчити протизапальну активність 11 різних екстрактів з листя шавлії лікарської (ШЛ) на моделі карагенінового набряку.

Методи дослідження. Експеримент виконано на білих безпородних щурах-самцях масою 200-250 г. Екстракти вводили внутрішньошлунково в діапазоні доз 10-100 мг/кг через 1 год, після чого в задню кінцівку субплантарно вводили 1 мл 0,1% розчину карагеніну. Фіксували об'єм набряку щогодини протягом 4 год. Препарат порівняння - диклосренак натрію.

Результати й обговорення. Встановлено протизапальну активність 9 з 11 екстрактів. Екстракт на основі відвару ШЛ (екстракт № 1), екстракт, отриманий шляхом екстрагування 50 \% етанолом (екстракт № 2), френольний екстракт ШЛ з додаванням L-лізину (екстракт № 4) та комплекс гідроксикоричних сполук ШЛ (екстракт №11) зменшували запалення протягом як альтеративної, так і ексудативної фраз запалення на 31-100% (р<0,05). Фенольний комплекс, очищений від амінокислот та іонів металів (екстракт № 7), сапоніновий комплекс (екстракт № 8), сумарний френольний комплекс (екстракт № 9) та фрлавоноїдний комплекс (екстракт № 10) зменшували запалення лише на фразі альтерації (зменшення набряку - 26-67 \%, p<0,05). Зменшував запалення під час ексудативної фрази екстракт, одержаний шляхом екстрагування 96 \% етанолом (екстракт № 3). Зменшення ексудації на його тлі становило 73-90 \% (p<0,05). За цих умов тільки комплекс френольних сполук у суміші з L-аргініном (екстракт № 5) ma полісахаридний комплекс із листя ШЛ (екстракт №6) не проявили антиексудативної активності.

Висновки. Отримані дані характеризують досліджувані екстракти з листя ШЛ (окрім екстрактів № 5 та 6) як ефрективні протизапальні засоби, що здатні редукувати запальний процес, який розвивається за циклооксигеназним шляхом. Усі досліджувані субстанції не поступалися за протизапальною активністю диклосренаку натрію. Одержані результати обумовлюють необхідність подальшого експериментального та клінічного дослідження листя ШЛ і засобів на його основі.

КЛЮЧОВІ СЛОВА: шавлія лікарська; екстракт; запалення; протизапальна дія; експеримент.

ВСТУП. Гостре та хронічне запалення є провідною ланкою патогенезу низки поширених захворювань. Для лікування станів, що супроводжуються запаленням, застосовують стероїдні та нестероїдні протизапальні засоби [1]. Проте клінічна ефективність цих ліків, а також безпека їх використання в різних категорій хворих часто бувають недостатніми. Тому пошук нових більш есрективних та безпечних протизапальних засобів $€$ актуальним завданням сучасної фрармації [2].

Шавлія лікарська (ШЛ, Salvia officinalis L.) $€$ перспективною лікарською рослиною для використання в медицині з метою терапії станів, що супроводжуються запальним процесом. Ії̈ здавна застосовують у народній та офріцинальній

(c) Ю. В. Верховодова, І. В. Кіреєв, О. М. Кошовий, М. М. Мига, 2019. медицині як протизапальний, антибактеріальний, протигрибковий засіб [3]. Протизапальна активність лікарської рослинної сировини ШЛ зумовлена великим спектром біологічно активних компонентів, що входять до її складу, серед яких провідне місце посідають терпеноїди та френольні сполуки [4].

Незважаючи на те, що срармакологічну активність ШЛ і традиційних галенових препаратів на її основі (настойки, екстракту) достатньо вивчено, в науковій літературі практично відсутні дані про фрармакологічне дослідження окремих фрракцій екстракту ШЛ. Мало того, залишається невідомим вплив на запалення екстрактів ШЛ у комплексі з фрармакологічними агентами, що можуть потенціювати їх протизапальну дію, наприклад, амінокислотами. Тому метою дослі- 
дження було вивчити протизапальну активність 11 різних екстрактів з листя шавлії лікарської, зокрема таких, що містять у своєму складі амінокислоту лізин чи аргінін, на моделі карагенінового набряку.

МЕТОДИ ДОСЛІДЖЕННЯ. Екстракти ШЛ отримано на кафредрі фрармакогнозії Національного фрармацевтичного університету під керівництвом д-ра фрармац. наук, профр. О. М. Кошового. Якісний склад досліджуваних екстрактів наведено в таблиці 1.

Дослідження протизапальної активності екстрактів ШЛ проводили на білих безпородних щурах обох статей масою 200-250 г, отриманих із віварію Інституту мікробіології та імунології ім. І. І. Мечникова. Антиексудативну активність екстрактів вивчали на моделі гострого запального набряку, викликаного субплантарним введенням у задню кінцівку тварин 0,1 мл 1 \% розчину карагеніну (агент, що індукує циклооксигеназний шлях запальної реакції) через 1 год після інтрагастрального введення водного розчину досліджуваного екстракту. Об'єм лапки вимірювали за допомогою онкометра до початку досліду і щогодини протягом 4 год [5]. Перед введенням екстрактів тварини голодували впродовж 3 год.

Таблиця 1 - Загальна характеристика, якісний склад досліджуваних екстрактів

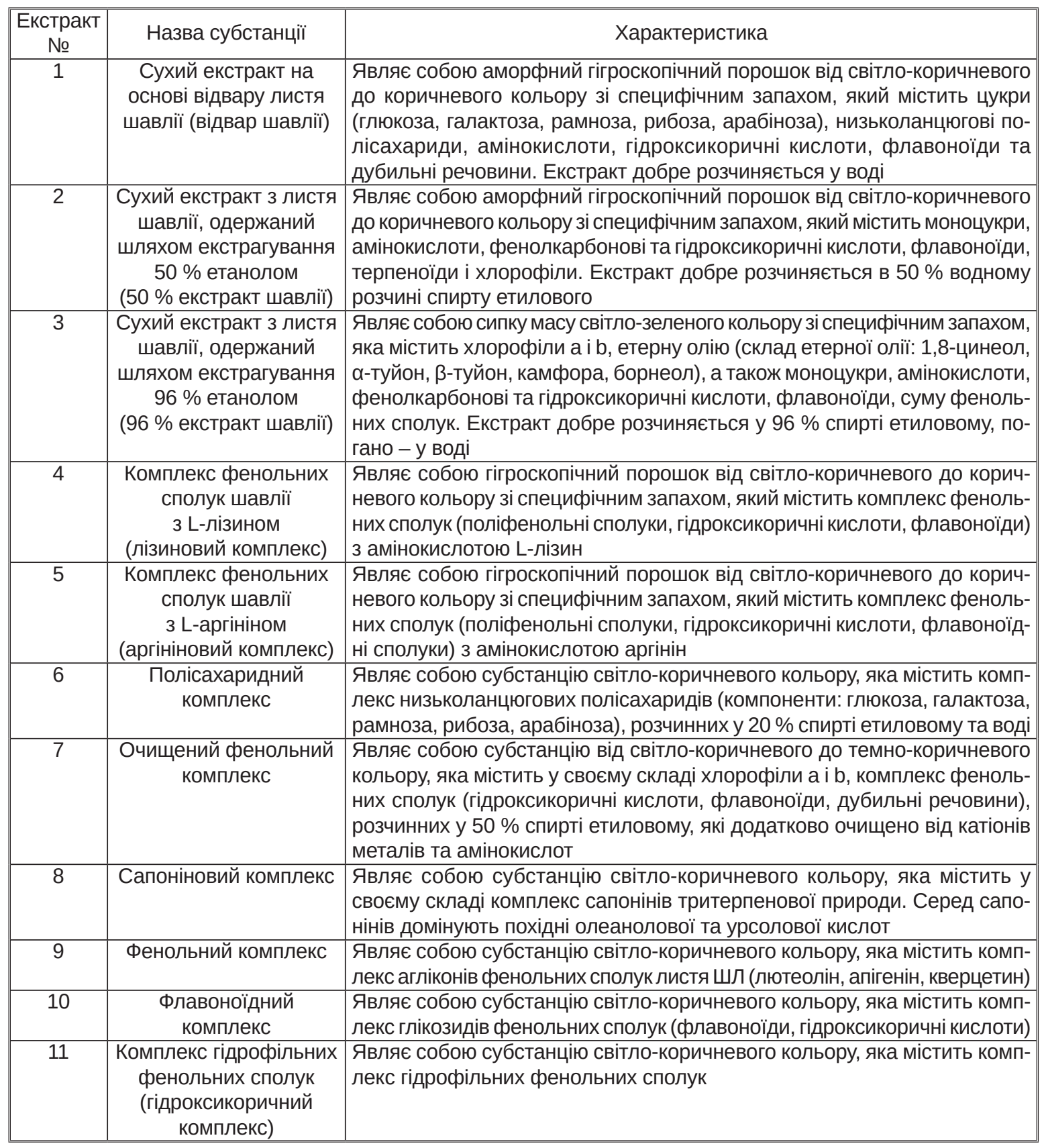


Екстракти № 1 і 2 вводили у дозах 50 та 70 мг/кг, № 3 - 70 і 100 мг/кг (по 6 щурів у кожній групі). Екстракти № 4, 5, 6, 7, 8, 9, 10, 11 вводили у дозах 10, 20, 50, 70 мг (по 6 тварин у кожній групі). Як препарат порівняння використовували диклосренак натрію в дозі 8 мг/кг, який вводили в режимі, аналогічному режиму введення екстрактів. Група інтактного контролю (IK) та група порівняння містили по 5 щурів.

Антиексудативну активність розраховували за фрормулою:

$$
A A=100 \%-\left(\frac{(\text { Уд }- \text { Удп) } 100}{(\text { Кк }- \text { Vкп })}\right)
$$

де AA - антиексудативна активність;

Vд - об'єм дослідної лапки;

Vдп - початковий об'єм дослідної лапки;

Vк- об'єм лапки тварини контрольної групи;

Vкп - початковий об'єм лапки тварини контрольної групи.

Утримання і догляд за щурами відповідали положенням Європейської конвенції про захист хребетних тварин, що використовуються для дослідних та інших наукових цілей (Страсбург, 1986) [6].

Отримані результати представлено у вигляді середнього та його стандартного відхилення $(\mathrm{M} \pm \mathrm{SD})$. Статистичний аналіз міжгрупових відмінностей виконано з використанням t-критерію Стьюдента з поправкою Єйтса на множинні порівняння. Статистично значущими вважали результати при $\mathrm{p} \leq 0,05$ [7].

РЕЗУЛЬТАТИ Й ОБГОВОРЕННЯ. ЧИсЛОВі показники антиексудативної активності екстрактів 3 листя ШЛ наведено в таблиці 2.

У щурів групи IK введення карагеніну спричинило набряк кінцівки, що проявилося зростанням її об'єму на 35,1 \% на 1 год 3 поступовим збільшенням до 50,0 \% на 4 год (табл. 2). Антиексудативна активність препарату порівняння - диклофенаку натрію становила 74,0-98,0 \% ( $<<0,05$ проти показника IK). Його протинабрякова дія за цих умов проявлялася протягом усього періоду спостереження (від 1 до 4 год), поступово посилюючись на 4 год. Це вказує на виражену протизапальну дію диклофенаку натрію, добре описану в публікаціях про експериментальні та клінічні дослідження даного лікарського засобу [8].

Деякі 3 досліджуваних екстрактів, у свою чергу, також продемонстрували антиексудативну активність у щурів із карагеніновим набряком. За впливом на об'єм лапки у тварин після субплантарного введення карагеніну досліджувані екстракти ШЛ можна поділити на чотири категорії: 1) ті, що не мали статистично значущого впливу на цей показник; 2) ті, що зменшували набряк протягом усього періоду спостереження (з 1-ї до 4-ї год); 3) ті, що змешували набряк лише на початку спостереження (1-2 год); 4) ті, що редукували набряк лапки наприкінці спостереження (3-4 год). Екстрактами, що не мали статистично значущого впливу на об'єм кінцівки щурів після введення агента, який спричиняє запальну реакцію, виявилися субстанції № 5 та 6 - комплекс френольних сполук ШЛ у суміші 3 L-аргініном (аргініновий комплекс) і полісахаридний комплекс шЛ відповідно. У випадку 3 екстрактом № 5 відсутність протизапальної активності можна аргументувати тим, що наявний у його складі L-аргінін може включатися в метаболічні шляхи запальної реакції, посилюючи її. Відомо, що на ранніх стадіях запалення L-аргінін слугує субстратом для утворення одного з медіаторів цього патологічного процесу - газоподібного оксиду азоту (II). Більше того, на стадії проліфрерації L-аргінін може перетворюватися на інші біомолекули (наприклад, пролін та поліаміни), які відіграють провідну роль у запальній реакції [9]. Отримані експериментальні дані щодо відсутності в екстракту ШЛ 3 L-аргініном (екстракт № 5) протизапальної активності добре співвідносяться з результатами експерименту, які ми одержали, стосовно наявності в цього комплексу діуретичної активності [10]. Оскільки патогенетично посилення діурезу та пригнічення синтезу простагландинів (протизапальна дія) $€$ взаємовиключними процесами, можна зробити висновок про те, що комплекс екстракту ШЛ 3 L-аргініном діє як активатор синтезу простагландинів, а не його інгібітор, що дозволяє вважати його потенційним діуретичним, але не протизапальним, засобом.

щодо екстракту № 6 слід зазначити, що для полісахаридного комплексу більш характерне провокування запалення, аніж протизапальна дія. Одним із механізмів, що пояснюють прозапальний ефект високомолекулярних полісахаридів при прийманні всередину, є посилення інсрільтрації слизової оболонки шлунково-кишкового тракту макрофрагами та її ушкодження, опосередковане лізосомальними ензимами цих імунокомпетентних клітин [11].

До категорії екстрактів ШЛ, які проявляли антиексудативну активність протягом 1-4 год спостереження, належать: екстракти № 1, 2, 4 та 11 (екстракт на основі відвару листя Шл; екстракт, отриманий шляхом екстрагування $50 \%$ розчином етанолу; френольний екстракт ШЛ 3 додаванням L-лізину; комплекс гідроксикоричних сполук ШЛ). Що стосується екстракту № 11, то було відмічено залежність протизапального ефректу від дози. У діапазоні доз 10-70 мг/кг він зменшував набряк лапки протягом 1-2 год спо- 


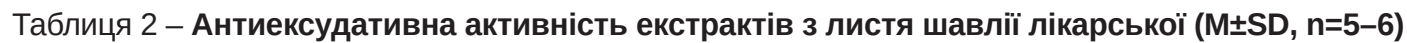

\begin{tabular}{|c|c|c|c|c|c|c|}
\hline \multirow{2}{*}{$\begin{array}{c}\text { Екстракт } \\
\text { № }\end{array}$} & \multirow{2}{*}{$\begin{array}{l}\text { Доза, } \\
\text { мг/кг }\end{array}$} & \multicolumn{5}{|c|}{ Об'єм лапки, ум. од. } \\
\hline & & $\begin{array}{c}\text { вихідний } \\
\text { рівень }\end{array}$ & 1 год & 2 год & 3 год & 4 год \\
\hline \multirow[t]{2}{*}{1} & 50 & $27,80 \pm 1,33$ & $32,50 \pm 2,43^{*}$ & $32,50 \pm 2,07^{*}$ & $31,20 \pm 2,23^{*}$ & $30,20 \pm 1,17^{*}$ \\
\hline & 70 & $26,80 \pm 1,94$ & $31,20 \pm 1,94^{*}$ & $31,30 \pm 1,97 *$ & $28,70 \pm 3,72^{*}$ & $26,80 \pm 1,94^{*}$ \\
\hline \multirow[t]{2}{*}{2} & 50 & $33,30 \pm 2,50$ & $40,00 \pm 3,20$ & $36,00 \pm 2,30 *$ & $38,00 \pm 2,77^{\star}$ & $36,00 \pm 1,86^{\star}$ \\
\hline & 70 & $29,70 \pm 1,70$ & $38,00 \pm 2,23^{*}$ & $37,00 \pm 1,13^{*}$ & $36,00 \pm 1,83^{*}$ & $36,00 \pm 1,50$ * \\
\hline \multirow[t]{2}{*}{3} & 70 & $36,00 \pm 2,48$ & $40,30 \pm 3,80$ & $41,10 \pm 3,24$ & $41,60 \pm 2,76$ & $40,00 \pm 3,06^{\star}$ \\
\hline & 100 & $38,00 \pm 2,12$ & $40,10 \pm 2,12$ & $40,10 \pm 2,67$ & $41,00 \pm 3,04$ & $39,40 \pm 2,44^{*}$ \\
\hline \multirow[t]{4}{*}{4} & 10 & $28,20 \pm 2,14$ & $31,20 \pm 2,23^{*}$ & $31,20 \pm 3,19 *$ & $30,20 \pm 2,79 *$ & $29,20 \pm 2,56^{\star}$ \\
\hline & 20 & $25,70 \pm 1,75$ & $29,30 \pm 2,07^{*}$ & $30,70 \pm 2,42^{*}$ & $29,30 \pm 1,63^{*}$ & $28,70 \pm 2,07^{*}$ \\
\hline & 50 & $27,50 \pm 1,87$ & $29,80 \pm 1,17^{*}$ & $29,70 \pm 2,66^{\star}$ & $28,50 \pm 2,07^{*}$ & $28,70 \pm 1,75^{\star}$ \\
\hline & 70 & $25,00 \pm 1,79$ & $28,30 \pm 2,25^{*}$ & $28,80 \pm 2,04^{*}$ & $27,50 \pm 2,59 *$ & $26,80 \pm 1,47^{*}$ \\
\hline \multirow[t]{4}{*}{5} & 10 & $27,20 \pm 2,14$ & $31,00 \pm 2,19$ & $34,00 \pm 1,90$ & $36,30 \pm 1,37$ & $41,30 \pm 3,01$ \\
\hline & 20 & $30,30 \pm 1,75$ & $37,20 \pm 3,19$ & $39,30 \pm 1,86$ & $43,80 \pm 2,04$ & $46,00 \pm 5,14$ \\
\hline & 50 & $32,00 \pm 2,28$ & $36,20 \pm 3,60$ & $39,20 \pm 3,60$ & $43,30 \pm 5,05$ & $45,50 \pm 5,32$ \\
\hline & 70 & $31,20 \pm 2,32$ & $35,80 \pm 1,94$ & $41,00 \pm 2,28$ & $44,30 \pm 3,01$ & $47,20 \pm 3,54$ \\
\hline \multirow[t]{4}{*}{6} & 10 & $32,50 \pm 2,17$ & $37,20 \pm 3,13$ & $39,20 \pm 3,13$ & $41,70 \pm 3,39$ & $45,80 \pm 3,49$ \\
\hline & 20 & $29,80 \pm 3,71$ & $36,80 \pm 2,64$ & $40,00 \pm 4,29$ & $42,30 \pm 3,98$ & $45,30 \pm 3,20$ \\
\hline & 50 & $32,30 \pm 2,07$ & $36,50 \pm 1,38$ & $39,20 \pm 3,66$ & $43,30 \pm 4,18$ & $45,70 \pm 3,27$ \\
\hline & 70 & $29,00 \pm 4,15$ & $33,70 \pm 2,58$ & $37,70 \pm 3,33$ & $41,20 \pm 2,48$ & $44,80 \pm 3,60$ \\
\hline \multirow[t]{4}{*}{7} & 10 & $28,20 \pm 2,93$ & $33,30 \pm 3,61^{*}$ & $37,70 \pm 2,34^{*}$ & $41,20 \pm 3,43$ & $42,80 \pm 1,94$ \\
\hline & 20 & $31,50 \pm 3,27$ & $35,80 \pm 2,14^{*}$ & $40,20 \pm 4,07$ & $43,80 \pm 3,06$ & $45,70 \pm 2,80$ \\
\hline & 50 & $30,00 \pm 1,79$ & $35,00 \pm 2,37^{*}$ & $39,20 \pm 2,14$ & $42,00 \pm 1,67$ & $45,70 \pm 2,16$ \\
\hline & 70 & $30,50 \pm 3,27$ & $35,30 \pm 3,72^{*}$ & $38,80 \pm 4,31$ & $42,80 \pm 4,45$ & $45,00 \pm 3,16$ \\
\hline \multirow[t]{4}{*}{8} & 10 & $32,30 \pm 2,34$ & $37,30 \pm 3,39$ & $40,70 \pm 2,42$ & $43,20 \pm 2,32$ & $46,20 \pm 2,23$ \\
\hline & 20 & $30,20 \pm 3,82$ & $35,30 \pm 3,33^{*}$ & $39,70 \pm 3,78$ & $42,50 \pm 3,73$ & $45,30 \pm 2,88$ \\
\hline & 50 & $31,00 \pm 3,16$ & $34,80 \pm 2,64^{*}$ & $38,70 \pm 3,93$ & $42,70 \pm 4,76$ & $44,70 \pm 3,50$ \\
\hline & 70 & $30,80 \pm 3,87$ & $34,30 \pm 2,73^{\star}$ & $38,30 \pm 2,73$ & $40,70 \pm 3,39$ & $42,70 \pm 4,80$ \\
\hline \multirow[t]{4}{*}{9} & 10 & $30,70 \pm 3,33$ & $34,20 \pm 1,72^{*}$ & $38,50 \pm 1,22^{*}$ & $43,00 \pm 2,53$ & $49,70 \pm 2,58$ \\
\hline & 20 & $31,20 \pm 3,19$ & $35,20 \pm 1,94^{*}$ & $38,80 \pm 3,49$ & $43,20 \pm 3,97$ & $44,70 \pm 1,97$ \\
\hline & 50 & $31,30 \pm 1,63$ & $34,80 \pm 1,72^{*}$ & $38,80 \pm 0,75^{*}$ & $42,00 \pm 1,26$ & $45,50 \pm 2,17$ \\
\hline & 70 & $29,50 \pm 3,45$ & $34,30 \pm 3,27^{*}$ & $38,00 \pm 3,58$ & $41,20 \pm 3,87$ & $44,70 \pm 3,27$ \\
\hline \multirow[t]{4}{*}{10} & 10 & $30,30 \pm 1,86$ & $34,20 \pm 1,47^{*}$ & $39,20 \pm 1,72$ & $41,20 \pm 1,72$ & $42,70 \pm 1,21$ \\
\hline & 20 & $31,30 \pm 2,88$ & $35,80 \pm 2,99 *$ & $39,80 \pm 4,02$ & $42,80 \pm 4,45$ & $45,50 \pm 3,73$ \\
\hline & 50 & $31,80 \pm 2,93$ & $36,70 \pm 2,94$ & $39,80 \pm 3,54$ & $42,80 \pm 3,76$ & $45,80 \pm 3,13$ \\
\hline & 70 & $28,50 \pm 2,26$ & $33,30 \pm 2,80 *$ & $36,80 \pm 2,86^{*}$ & $39,00 \pm 3,35$ & $40,80 \pm 3,06$ \\
\hline \multirow[t]{4}{*}{11} & 10 & $30,20 \pm 1,72$ & $33,70 \pm 2,07^{*}$ & $36,30 \pm 2,07 *$ & $39,70 \pm 2,50$ & $41,00 \pm 2,50$ \\
\hline & 20 & $30,30 \pm 3,08$ & $33,00 \pm 3,22^{*}$ & $35,30 \pm 3,61^{*}$ & $36,80 \pm 3,31^{*}$ & $38,00 \pm 3,44^{*}$ \\
\hline & 50 & $32,20 \pm 2,71$ & $35,50 \pm 2,43^{*}$ & $38,30 \pm 3,20$ & $41,00 \pm 2,53$ & $44,00 \pm 2,07$ \\
\hline & 70 & $29,30 \pm 2,80$ & $32,30 \pm 2,42^{*}$ & $35,20 \pm 1,47^{*}$ & $38,20 \pm 1,72^{*}$ & $40,20 \pm 2,64$ \\
\hline $\begin{array}{l}\text { Інтактний } \\
\text { контроль }\end{array}$ & - & $30,20 \pm 5,26$ & $40,80 \pm 3,63$ & $41,40 \pm 1,95$ & $44,20 \pm 4,27$ & $46,20 \pm 5,07$ \\
\hline $\begin{array}{c}\text { Диклофенак } \\
\text { натрію }\end{array}$ & 8 & $33,40 \pm 2,07$ & $33,60 \pm 1,67^{*}$ & $35,80 \pm 2,86^{\star}$ & $37,00 \pm 5,15^{\star}$ & $34,60 \pm 2,07^{*}$ \\
\hline
\end{tabular}

Примітка. * - відмінності статистично значущі $($ <<0,05) порівняно з контролем.

стереження, в дозі 20 мг/кг - упродовж 3-4 год, а в дозі 70 мг/кг - протягом 1-3 год. Таким чином, найефективнішою є доза 20 мг/кг цього екстракту (АA - 50-75 \%). Протизапальна дія екстрактів № 1 та 2 проявилася в дозах 50-70 мг/кг, тоді як екстракт № 4 зменшував запалення в більш широкому діапазоні доз (10-70 мг/кг). При цьому антиексудативний ефект екстракту № 4 був дозозалежним, поступово зростаючи зі збільшенням дози до 50 мг/кг (максимальна AA 94 \%) та дещо знижуючись у дозі 70 мг/кг. Отже, AА екстракту № 1 у дозі 70 мг/кг становила 59-100\% (p<0,05), екстракту № 2 (50 мг/кг) -
33-84 \% (p<0,05), екстракту № 4 (50 мг/кг) 78-93 \% $(p<0,05)$. Отримані дані вказують на виражені протизапальні властивості досліджуваних екстрактів. Та обставина, що екстракти № 1, 2 та 4 зменшували запальний набряк лапки щурів протягом усього періоду спостереження, свідчить про їх позитивний вплив як на альтеративну фразу запалення, так і на ексудативну.

До екстрактів, які зменшували набряк лапки протягом 1-2 год спостереження, належать субстанції № 7, 8, 9 та 10 (фенольний комплекс, очищений від амінокислот та іонів металів; сапоніновий комплекс; сумарний френольний комп- 
лекс; фрлавоноїдний комплекс). При цьому екстракт № 7 зменшував запалення протягом 1 год спостереження в діапазоні доз 10-70 мг/кг (АА - 51-59 \%), екстракт № 8 - також упродовж 1 год у діапазоні доз 20-70 мг/кг (АА - 51-67 \%); АА екстракту № 9 протягом 1 год у діапазоні доз 20-70 мг/кг становила 54-67 \%, екстракту № 10 на 1 год - 54-64 \% у дозах 10, 20, 70 мг/кг, а на 2 год - $26 \%$ у дозі 70 мг/кг (р<0,05 проти групи ІК для всіх зазначених показників). Отримані дані свідчать про здатність екстрактів № 7-10 редукувати альтеративну фразу запалення, спричинену карагеніном.

Єдиним екстрактом ШЛ, який зменшував спричинений карагеніном набряк лапки щурів наприкінці спостереження (на 4 год), став екстракт № 3 (отриманий шляхом екстрагування $96 \%$ етанолом). На його тлі АА становила $73 \%$ (доза 70 мг/кг) та 90 \% (доза 100 мг/кг, р<0,05 проти показника групи IК). Здатність екстракту № 3 зменшувати запальну реакцію на 4 год спостереження свідчить про те, що максимум його протизапальної активності припадає на ексудативну фразу запалення.

Таким чином, отримані експериментальні дані вказують на наявність вираженої протизапальної дії різних фрракцій екстракту ШЛ, що проявляється за умов циклооксигеназного запального процесу. Тільки полісахаридний комплекс екстракту ШЛ, а також френольний комплекс у суміші 3 L-аргініном при цьому не мають статистично значущого впливу на ексудацію, спричинену карагеніном. Для різних фрракцій екстракту ШЛ характерним $€$ вплив на окремі ланки запального процесу.

ВИСНОВКИ. 1. Досліджено вплив 11 екстрактів шавлії лікарської на запальний процес, спричинений індуктором циклооксигенази - ка- рагеніном. Встановлено, що 9311 екстрактів проявляють виражену антиексудативну активність, зменшуючи запалення лапки щурів на 26-100\%.

2. Екстрактами, що не проявили антиексудативної активності на моделі карагенінового набряку, стали комплекс фенольних сполук шавлії лікарської з L-аргініном (екстракт № 5) та полісахаридний комплекс рослини (екстракт № 6).

3. Зменшували запалення під час як альтеративної, так і ексудативної фраз екстракт на основі відвару листя шавлії лікарської (екстракт № 1), екстракт, отриманий шляхом екстрагування 50 \% етанолом (екстракт № 2), френольний екстракт шавлії лікарської з додаванням L-лізину (екстракт № 4) та комплекс гідроксикоричних сполук (екстракт № 11). Антиексудативна активність на їх тлі становила 31-100 \% ( $<<0,05$ проти показника групи інтактного контролю).

4. Екстрактами, що зменшували запальну реакцію під час альтеративної срази, стали френольний комплекс, очищений від амінокислот та іонів металів (екстракт № 7), сапоніновий комплекс (екстракт № 8), сумарний френольний комплекс (екстракт № 9) та фрлавоноїдний комплекс (екстракт № 10). Зменшення запалення на їх тлі становило 26-67 \% ( $<<0,05$ проти показника групи інтактного контролю).

5. Зменшував запалення під час ексудативної фази екстракт, отриманий шляхом екстрагування 96 \% етанолом (екстракт № 3). Зменшення ексудації на його тлі становило 73-90 \% ( $<<0,05$ проти показника групи інтактного контролю).

6. Шавлія лікарська та комплекси її біологічно активних речовин потребують подальшого експериментального і клінічного вивчення 3 метою створення нових безпечних та ефективних лікарських засобів.

\section{СПИСОК ЛІТЕРАТУРИ}

1. Medzhitov R. Origin and physiological roles of inflammation / R. Medzhitov // Nature. - 2008. - 454 (7203). - P. 428-435.

2. Nathan C. Nonresolving inflammation / C. Nathan, A. Ding // Cell. - 2010. - 140 (6). - P. 871-882.

3. Committee on herbal medicinal products. European Union herbal monograph on Salvia officinalis L., folium // Committee on herbal medicinal products. London, - 2016. URL : https://www.ema.europa.eu/en/ documents/herbal-monograph/final-european-unionherbal-monograph-salvia-officinalis---folium-revision-1_ en.pdf (accessed 04.10.2019).
4. Jakovljevic M. Bioactive profile of various salvia officinalis L. preparations: review / M. Jakovljevic, S. Jokic // Plants. - 2019. - 8. - Article 55.

5. Стефранов О. В. Доклінічні дослідження лікарських засобів : метод. рек. / О. В. Стесранов. - К. : Авіцена, 2001. - 528 с.

6 . European convention for the protection of vertebrate animals used for the experimental and other scientific purposes [Text]: European Treaty Series No. 123: Text amended according to the provisions of the Protocol (ETS No. 170), as of its entry into force, on 2 December 2005. Strasbourg, 1986. -48 p. 
7. Гланц М. Медико-биологическая статистика / под ред. Н. Е. Бузикашвили, Д. В. Самойлова ; пер. с англ. Ю. А. Данилова. - М. : Практика, 1998. - 459 с.

8. Gan T. J. Diclofenac: an update on its mechanism of action and safety profile / T. J. Gan // Current Medical Research and Opinion. - 2010. - 26 (7). - P. 1715-1731.

9. Satriano J. Arginine pathways and the inflammatory response: interregulation of nitric oxide and polyamines: review article / J. Satriano // Amino Acids. - 2004. 26 (4). - P. 321-329.
10. Дослідження впливу екстрактів листя шавлії лікарської на діурез у щурів / Ю. В. Верховодова, І. В. Кіреєв, О. М. Кошовий, М. М. Мига // Фармакологія та лікар. токсикологія. - 2019. - 13, № 4. - С. 249 254.

11. Tobacman J. K. Review of harmful gastrointestinal effects of carrageenan in animal experiments / J. K. Tobacman // Environmental Health Perspectives. 2001. - 109 (10). - P. 983-994.

\section{REFERENCES}

1. Medzhitov, R. (2008). Origin and physiological roles of inflammation. Nature, 454 (7203), 428-435.

2. Nathan, C., \& Ding, A. (2010). Nonresolving inflammation. Cell, 140 (6), 871-882.

3. (2016). Committee on herbal medicinal products. European Union herbal monograph on Salvia officinalis L., folium. Committee on herbal medicinal products. London. Retrieved from: https://www.ema.europa.eu/en/ documents/herbal-monograph/ final-european-unionherbal-monograph-salvia-officinalis-I-folium-revision-1 en.pdf (accessed 04.10.2019).

4. Jakovljevic, M., \& Jokic, S. (2019). Bioactive profile of various Salvia officinalis L. preparations: review. Plants, 8. Article 55.

5. Stefanov, O.V. (2001). Doklinichni doslidzhennia likarskykh zasobiv: metod. rekom. [Preclinical drug research: guidelines]. Kyiv: Avitsenna [in Ukrainian].

6 . European convention for the protection of vertebrate animals used for the experimental and other scientific purposes [Text]: European Treaty Series No. 123: Text amended according to the provisions of the Protocol
(ETS No. 170), as of its entry into force, on 2 December 2005. Strasbourg, 1986. 48 p.

7. Glantz, M. (1998). Mediko-biologicheskaya statistika [Medical and biological statistics]. Moscow: Praktika [in Russian].

8. Gan, T.J. (2010). Diclofenac: an update on its mechanism of action and safety profile. Current Medical Research and Opinion, 26 (7), 1715-1731.

9. Satriano, J. (2004). Arginine pathways and the inflammatory response: interregulation of nitric oxide and polyamines: review article. Amino Acids, 26 (4), 321-329.

10. Verkhovodova, Yu.V., Kireiev, I.V., Koshovyi, O.M., \& Myha, M.M. (2019). Doslidzhennia vplyvu ekstraktiv Iystia shavlii likarskoi na diurez u shchuriv [Investigation of the influence of Salvia officinalis leaves extracts on diuresis in rats]. Farmakolohiia ta likarska toksykolohiia Pharmacology and Drug Toxicology, 13 (4), 249-254 [in Ukrainain].

11. Tobacman, J.K. (2001). Review of harmful gastrointestinal effects of carrageenan in animal experiments. Environmental Health Perspectives, 109 (10), 983-994.

Ю. В. Верховодова, И. В. Киреев, О. Н. Кошевой, М. М. Мыга НАЦИОНАЛЬНЫЙ ФАРМАЦЕВТИЧЕСКИЙ УНИВЕРСИТЕТ, ХАРЬКОВ

\section{ИССЛЕДОВАНИЕ АНТИЭКСУДАТИВНОЙ АКТИВНОСТИ ЭКСТРАКТОВ ИЗ ЛИСТЬЕВ SALVIA OFFICINALIS}

\section{Резюме}

Вступление. Совершенствование фрармакотерапии воспаления является актуальной задачей современной фрармацевтической и медицинской науки.

Цель исследования - изучить противовоспалительную активность 11 различных экстрактов из листьев шалфея лекарственного (ШЛ) на модели каррагенинового отека.

Методы исследования. Эксперимент выполнен на белых беспородных крысах-самцах массой 200250 г. Экстракты вводили внутрижелудочно в диапазоне доз 10-100 мг/кг через 1 ч, после чего в заднюю конечность субплантарно вводили 1 мл 0,1% раствора каррагенина. Фиксировали объем отека каждый час в течение 4 ч. Препарат сравнения - диклофенак натрия.

Результаты и обсуждение. Установлена противовоспалительная активность 9 из 11 экстрактов. Экстракт на основе отвара ШЛ (экстракт №1), экстракт, полученный путем экстрагирования 50 \% эта- 
нолом (экстракт № 2), френольный экстракт ШЛ с добавлением L-лизина (экстракт № 4) и комплекс гидроксикоричных соединений ШЛ (экстракт № 11) уменьшали воспаление в течение как альтеративной, так и экссудативной фраз воспаления на 31-100\% (p<0,05). Фенольный комплекс, очищенный от аминокислот и ионов металлов (экстракт №7), сапониновый комплекс (экстракт № 8), суммарный френольный комплекс (экстракт №9) и фрлавоноидный комплекс (экстракт №10) уменьшали воспаление только на фразе альтерации (уменьшение отека - 26-67\%, р<0,05). Уменьшал воспаление во время экссудативной фразы экстракт, полученный путем экстрагирования 96 \% этанолом (экстракт № 3). Уменьшение экссудации на его фроне составило 73-90% (p<0,05). В этих условиях только комплекс френольных соединений в смеси c L-аргинином (экстракт №5) и полисахаридный комплекс из листьев ШЛ (экстракт №6) не проявили антиэкссудативной активности.

Выводы. Полученные данные характеризуют исследуемые экстракты из листьев ШЛ (кроме экстрактов № 5 и 6) как эфрфективные противовоспалительные средства, способные редуцировать воспалительный процесс, который развивается по циклооксигеназному пути. Все исследуемые субстанции не уступали по противовоспалительной активности диклофренаку натрия. Полученные результаты обусловливают необходимость дальнейшего экспериментального и клинического исследования листьев ШЛ и средств на его основе.

КЛЮЧЕВЫЕ СЛОВА: шалфей лекарственный; экстракт; воспаление; противовоспалительное действие; эксперимент.

Y. V. Verkhovodova, I. V. Kireyev, O. M. Koshovyi, M. M. Myha NATIONAL UNIVERSITY OF PHARMACY, KHARKIV

\section{INVESTIGATION OF ANTI-EXUDATIVE ACTIVITY OF SALVIA OFFICINALIS LEAVES EXTRACTS}

\section{Summary}

Introduction. Improving of the pharmacotherapy of inflammation is an urgent task of modern pharmaceutical and medical science.

The aim of the study - to investigate the anti-inflammatory activity of 11 different extracts from the leaves of Common Sage (CS) on the model of carrageenan edema.

Research Methods. The experiment was performed on white outbred male rats weighing 200-250 g. The extracts were administered intragastrically in a dose range of $10-100 \mathrm{mg} / \mathrm{kg}$, an hour later, $1 \mathrm{ml}$ of a $0.1 \%$ carrageenan solution was injected into the hind limb. The volume of edema was evaluated every hour for 4 hours. The comparison drug is diclofenac sodium.

Results and Discussion. Anti-inflammatory activity of 9 of 11 extracts was found out. The extract obtained from decoction of CS (extract No. 1), the extract obtained by extraction with $50 \%$ ethanol (extract No. 2), the phenolic extract of CS with the addition of L-lysine (extract No. 4), and the complex of hydroxycinnamic compounds of CS (extract No. 11) reduced inflammation in the course of both the alternative and exudative phases of inflammation by $31-100 \%(p<0.05)$. Phenolic complex purified from amino acids and metal ions (extract No. 7), saponin complex (extract No. 8), total phenolic complex (extract No. 9) and flavonoid complex (extract No. 10) reduced inflammation only at the alteration phase (reduction of edema 26-67\%, p<0.05). The extract obtained by extraction with $96 \%$ ethanol (extract No. 3) reduced edema only during the exudative phase. The decrease in exudation against its background was $73-90 \%(p<0.05)$. Under these conditions, only the complex of phenolic compounds mixed with L-arginine (extract No. 5) and the polysaccharide complex from the leaves of CS (extract No. 6) did not exhibit antiexudative activity.

Conclusions. The obtained data characterize the studied extracts from the leaves of CS (except for extracts No. 5 and 6) as effective anti-inflammatory drugs that can reduce the inflammatory process that develops along the cyclooxygenase pathway. All the studied substances were not inferior to the anti-inflammatory activity of diclofenac sodium. The obtained results determine the need for further experimental and clinical research of leaves of CS and agents based on its basis.

KEY WORDS: common sage; extract; inflammation; anti-inflammatory action; experiment.

Отримано 16.10 .19

Адреса для листування: Ю. В. Верховодова, Національний фармацевтичний університет, вул. Пушкінська, 53, Харків, 61000, україна, e-mail: juliaverh73@gmail.com. 